\title{
The Effect of Supporting Electrolyte on Ion Permeability Through Red Blood Cell Membrane
}

\author{
Benevolent Orighomisan Atolaiye ${ }^{1}$, Titilayo Oluwayemisi Bamidele ${ }^{2}$, \\ Douglas Uwagbale Edward-Ekpu, ${ }^{1, *}$ \\ ${ }^{1}$ Department of Chemistry, Nasarawa State University, Keffi, Nigeria \\ ${ }^{2}$ Department of Biochemistry and Molecular Biology, Nasarawa State University, Keffi, Nigeria
}

Email address:

mbatolaiye@yahoo.com (B. O. Atolaiye), titibamidele@yahoo.com (T. O. Bamidele), douglassony@yahoo.com (D. U. Edward-Ekpu) ${ }^{*}$ Corresponding author

\section{To cite this article:}

Benevolent Orighomisan Atolaiye, Titilayo Oluwayemisi Bamidele, Douglas Uwagbale Edward-Ekpu. The Effect of Supporting Electrolyte on Ion Permeability Through Red Blood Cell Membrane. Cell Biology. Vol. 5, No. 2, 2017, pp. 12-16. doi: 10.11648/j.cb.20170502.11

Received: February 23, 2017; Accepted: March 14, 2017; Published: March 21, 2017

\begin{abstract}
This study was aimed at providing information on how Na sulphate, $\mathrm{K}$ sulphate, $\mathrm{Ca}$ sulphate and $\mathrm{Mg}$ sulphate supporting electrolytes affect the permeation of hypotonic $\mathrm{Na}$ chloride, $\mathrm{K}$ chloride, $\mathrm{Ca}$ chloride and $\mathrm{Mg}$ chloride ions through Red Blood Cell (RBC) membrane while the RBCs haemolyse using a UV/Vis spectrophotometer. The effects of the supporting electrolytes were deduced from the changes in their respective rates of permeation through $\mathrm{RBC}$ membranes during haemolysis. $\mathrm{Na}_{2} \mathrm{SO}_{4}$ added to $\mathrm{NaCl}$ and $\mathrm{MgSO}_{4}$ to $\mathrm{MgCl}_{2}$ resulted in a decrease in permeation rate of the resultant solutions while the addition of $\mathrm{K}_{2} \mathrm{SO}_{4}$ to $\mathrm{KCl}$ and the addition of $\mathrm{CaSO}_{4}$ to $\mathrm{CaCl}_{2}$ resulted in an increase in permeation rate. In this research there was no regular pattern of permeation and since $\mathrm{NaSO}_{4}$ and $\mathrm{MgSO}_{4}$ decreased $\mathrm{NaCl}$ and $\mathrm{MgCl}_{2}$ permeability respectively, then the increase in the permeability of $\mathrm{KCl}$ and $\mathrm{CaCl}_{2}$ may not be as a result of the increase of $\mathrm{K}^{+}$and $\mathrm{Ca}^{2+}$ concentration in $\mathrm{K}_{2} \mathrm{SO}_{4}+\mathrm{KCl}$ solution and $\mathrm{CaCl}_{2}{ }^{+} \mathrm{CaSO}_{4}$ solution respectively.
\end{abstract}

Keywords: Supporting Electrolyte, Permeability, Red Blood Cell, Membrane, Chlorides, Sulphates

\section{Introduction}

The addition of supporting electrolyte to an electrolyte solution can affect the ionic strength of that electrolyte solution [1]. According to IUPAC [2], a supporting electrolyte is an electrolyte solution, whose constituents are not electroactive in the range of applied potentials being studied, and whose concentration, ionic strength, and therefore contribution to conductivity is usually much larger than that of the electroactive substance to be dissolved in it. The supporting electrolyte is a strong electrolyte in high concentration in comparison to the concentration level of other ions in the medium. The effect of added electrolyte on the equilibria of a solution with ionic strength of $0.1 \mathrm{M}$ or less is independent of the chemical nature of the electrolyte but depends on the ionic strength. It also maintains constant ionic strength and constant $\mathrm{pH}$ [3]. Mature mammalian red blood cell (RBC) consist of a single compartment, simplifying many approaches for transport studies making mature erythrocytes from mammals a very easy-to use model for cell membrane transport studies intracellular constant measurements (ion or metabolite concentrations, $\mathrm{pH}$ ) and flux experiments are easier than in any other type of cell containing multiple compartments [4-6]. Ions enter and leave cells through the cell membrane which is a selective barrier and has a dynamic structure composed of two layers of phospholipid molecules interspersed with cholesterol and proteins. It regulates passage of water and ions through it [7]. The type of ions or electrolyte that is allowed to pass through a cell membrane and at what rate can be determined by certain physiological factors like tonicity and osmotic concentration [8-9]. Different electrolyte solutions can vary in the osmotic pressure they exert on a cell membrane, depending on the degree of dissociation of the particular electrolyte in the solvent. In order to understand ion permeation through red blood cell (RBC) membrane, chemical phenomenon (dissociation and ionisation); physiological phenomenon (haemolysis); physical properties 
(refractive index, dispersion or absorption of light) and optical density/turbidity (light scattering), have been used to study the electrochemical effects of individual electrons and protons on cell membrane, and the relationships correlating the number and energy states of electrons in ions and electrolytes with the observable properties shown by a cell system [8-12].

In the last few decades, researchers have shown numerous interests in the application of membranes in certain areas like pharmaceuticals, biotechnology, agriculture, food, medicine, etc. [1]. RBCs have been studied extensively, to determine the permeability across cell membrane but there exists a paucity of information on ion permeation through $\mathrm{RBC}$ membranes in electrolytes other than $\mathrm{KCl}$ and $\mathrm{NaCl}$ [9]. Experimental studies show that supporting electrolyte concentration has a marked influence on ion transport rate [13]. Okolue et al. [1], studied the effect of supporting electrolyte on permeation of ions through a polymeric membrane. The result shows that there was a rapid increase in the rate of permeation of $\mathrm{NaCl}, \mathrm{CaCl}_{2}$ and $\mathrm{AlCl}_{3}$ electrolytes supported by $\mathrm{Na}_{2} \mathrm{SO}_{4}, \mathrm{CaSO}_{4}$ and $\mathrm{Al}_{2}\left(\mathrm{SO}_{4}\right)$ electrolytes respectively. They reported that this increase was as a result of an increase in the concentration of $\mathrm{Na}^{+}, \mathrm{Ca}^{2+}$, and $\mathrm{Al}^{3+}$ ions in the resultant mixture. The observation of this research may not explain the effect of supporting electrolyte on ion migration across a biological membrane.

This study is aimed at providing information on how supporting electrolytes affect permeation of ions through RBC membrane by determining the rate at which ions of hypotonic $\mathrm{NaCl}, \mathrm{KCl}, \mathrm{CaCl}_{2}$ and $\mathrm{MgCl}_{2}$ at $\mathrm{pH} 7.4$ haemolyse $\mathrm{RBC}$ and the rate at which ions of hypotonic mixture of $\mathrm{NaCl}+\mathrm{Na}_{2} \mathrm{SO}_{4}, \quad \mathrm{~K}_{2} \mathrm{SO}_{4}+\mathrm{KCl}, \quad \mathrm{CaCl}_{2}+\mathrm{CaSO}_{4} \quad$ and $\mathrm{MgCl}_{2}+\mathrm{MgSO}_{4}$ at $\mathrm{pH} 7.4$ haemolyse $\mathrm{RBC}$ using haemolysis as a marker while apply UV/Vis spectrophotometry to monitor the haemolysis process. Haemolysis time is used as an index as to the rate of osmosis of penetrating molecules into the cell [12]. The amount of time that it takes for haemolysis or crenation to occur is directly related to the rate of permeation across the cell membrane [14]. Therefore, the rate of haemolysis can also be used as an indicator of the permeability for a particular penetrating solutes $[8,10,15]$. A transient turbidity measurement from a given blood/test solution, prepared by adding blood to that test solution, can give a quantitative index of the permeability coefficient of the substance being tested. Thus, from such measurements, one can deduce relative permeability for each of the test substances [9].

\section{Materials and Methods}

Isotonic solutions of $\mathrm{NaCl}(160 \mathrm{mM}), \mathrm{KCl}(160 \mathrm{mM})$, $\mathrm{CaCl}_{2}(110 \mathrm{mM})$ and $\mathrm{MgCl}_{2} \cdot 6 \mathrm{H}_{2} \mathrm{O}(110 \mathrm{mM})$ at $\mathrm{pH} 7.4$ and solutions of $\mathrm{NaCl}(18 \mathrm{mM})+\mathrm{Na}_{2} \mathrm{SO}_{4}(180 \mathrm{mM}),+\mathrm{KCl}(18$ $\mathrm{mM})+\mathrm{K}_{2} \mathrm{SO}_{4}(180 \mathrm{mM}), \mathrm{CaCl}_{2}(26 \mathrm{mM})+\mathrm{CaSO}_{4}(260$ $\mathrm{mM})$ and $\mathrm{MgCl}_{2}(26 \mathrm{mM})+\mathrm{MgSO}_{4}(260 \mathrm{mM})$ at $\mathrm{pH} 7.4$ were prepared taking into account their molecular weight and osmotic concentration. Each of the isotonic solutions (25 $\mathrm{mL}$ ) mentioned above were diluted with $25 \mathrm{~mL}$ of distilled water to give half their initial concentration (50\% hypotonicity). Blood $(20 \mathrm{~mL})$ collected in acid-citratedextrose $(A C D)$ was washed thrice with isotonic saline and the RBC separated. Each hypotonic solution $(1.5 \mathrm{~mL})$ prepared was mixed with $0.05 \mathrm{~mL}$ of $\mathrm{RBC}$ suspension and their absorbance/min for $16 \mathrm{~min}$ were measured using a $\mathrm{UV} / \mathrm{Vis}$ spectrophotometer while the RBCs haemolyse. The absorbance of each solution were recorded. The data were used to plot graphs with the time ( $\mathrm{min})$ on the $\mathrm{x}$-axis and the absorbance $(\AA)$ on the y-axis. Logarithmic trendlines were used to analyse the graph to understand the correlationship and the interrelationship of the variables of this study.

\section{Results and Discussion}

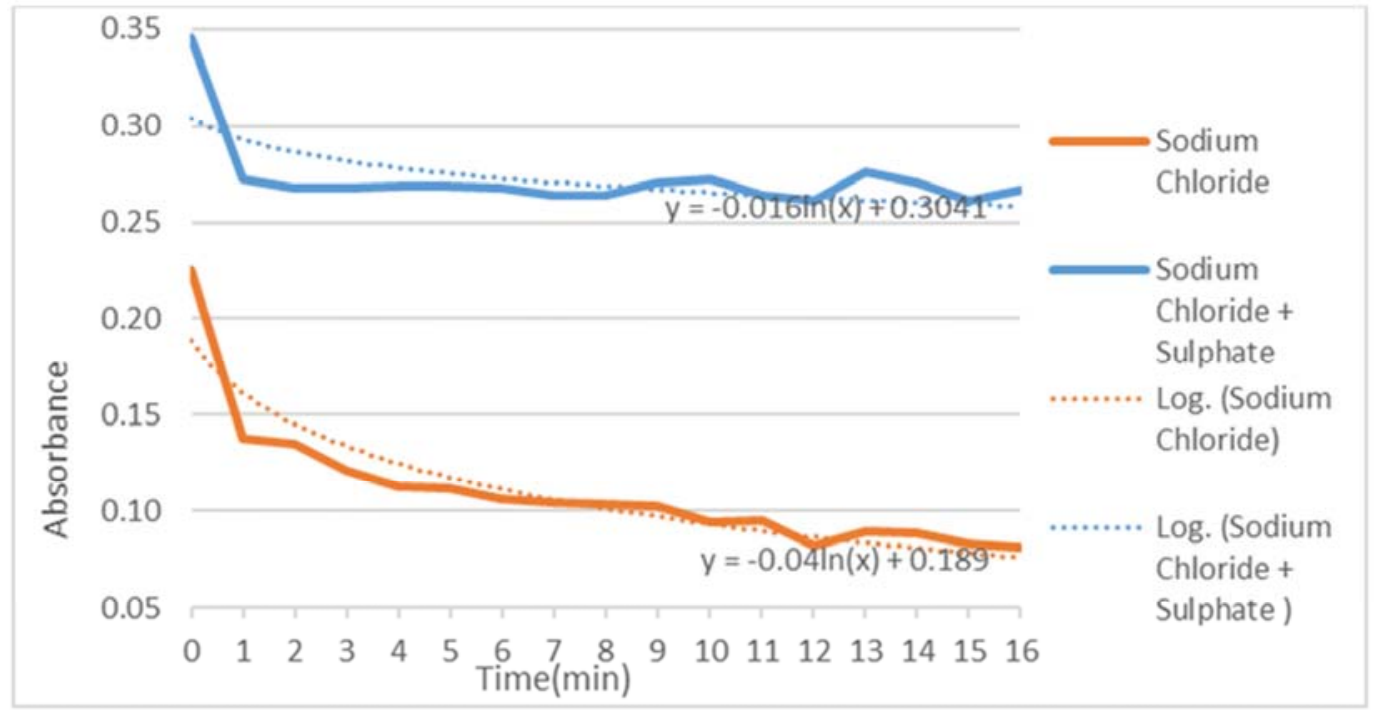

Figure 1. Effect of $\mathrm{Na}_{2} \mathrm{SO}_{4}$ on $\mathrm{NaCl}$ electrolyte permeability through $\mathrm{RBC}$ membrane. 


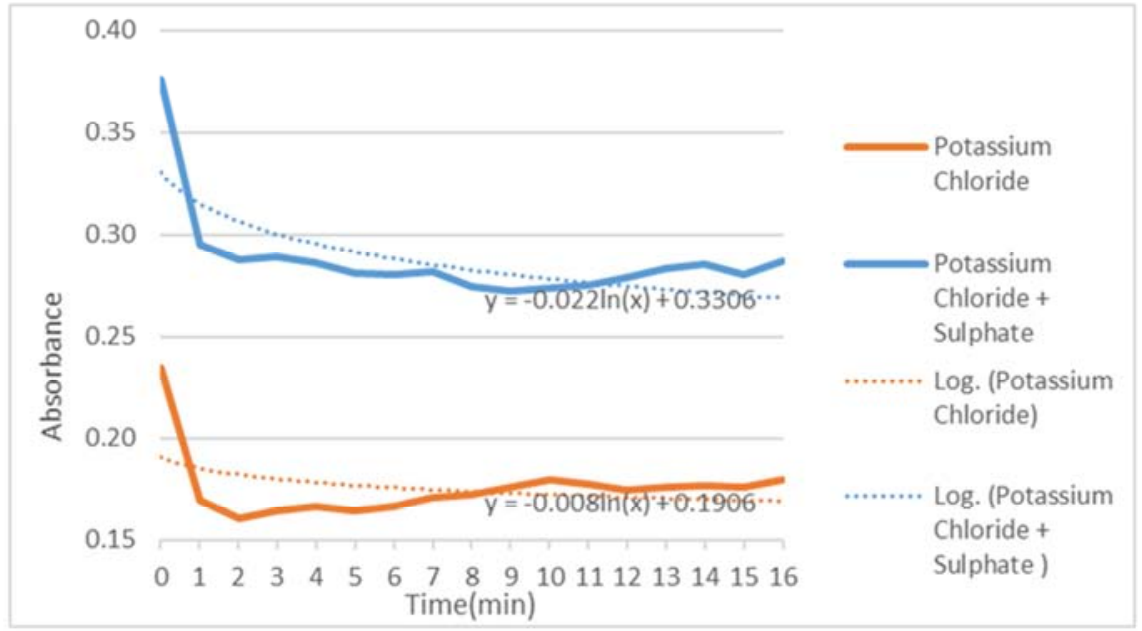

Figure 2. Effect of $\mathrm{K}_{2} \mathrm{SO}_{4}$ on $\mathrm{KCl}$ electrolyte permeability through $\mathrm{RBC}$ membrane.

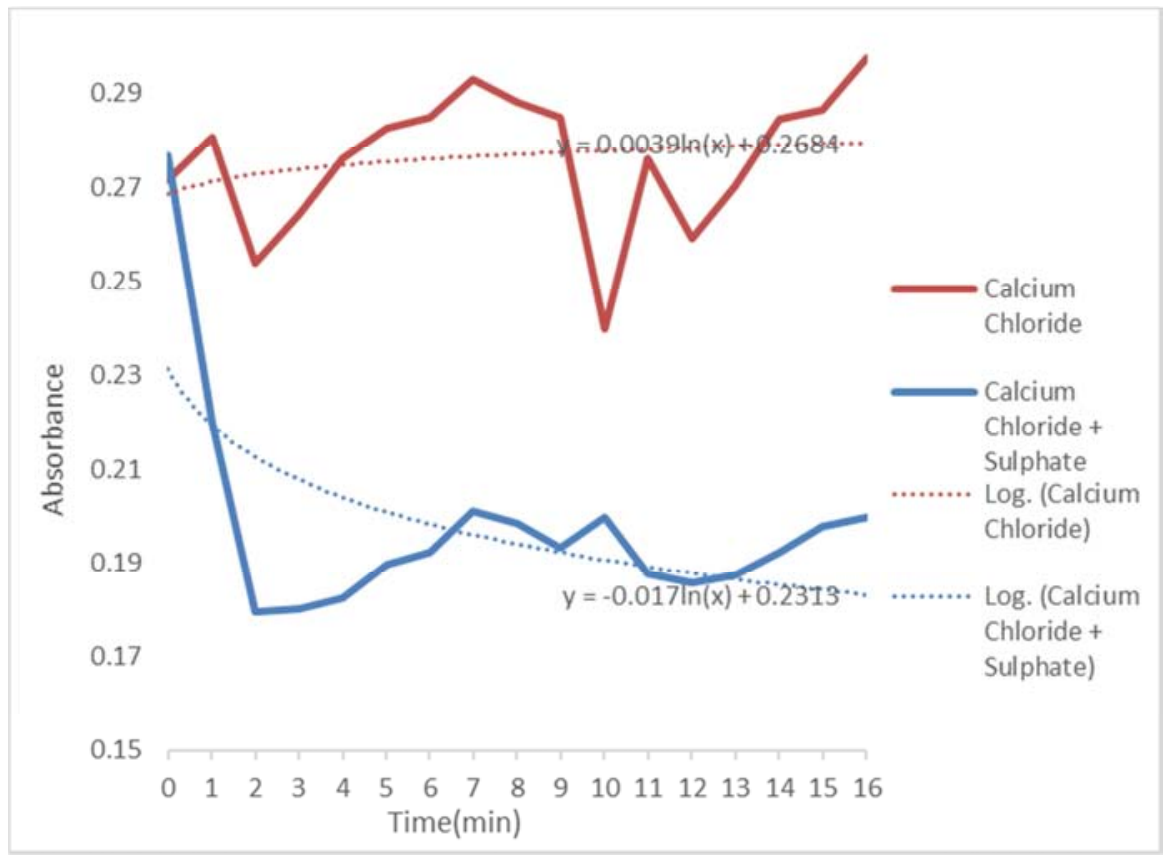

Figure 3. Effect of $\mathrm{CaSO}_{4} \cdot 2 \mathrm{H}_{2} \mathrm{O}$ on $\mathrm{CaCl}_{2}$ electrolyte permeability through $\mathrm{RBC}$ membrane.

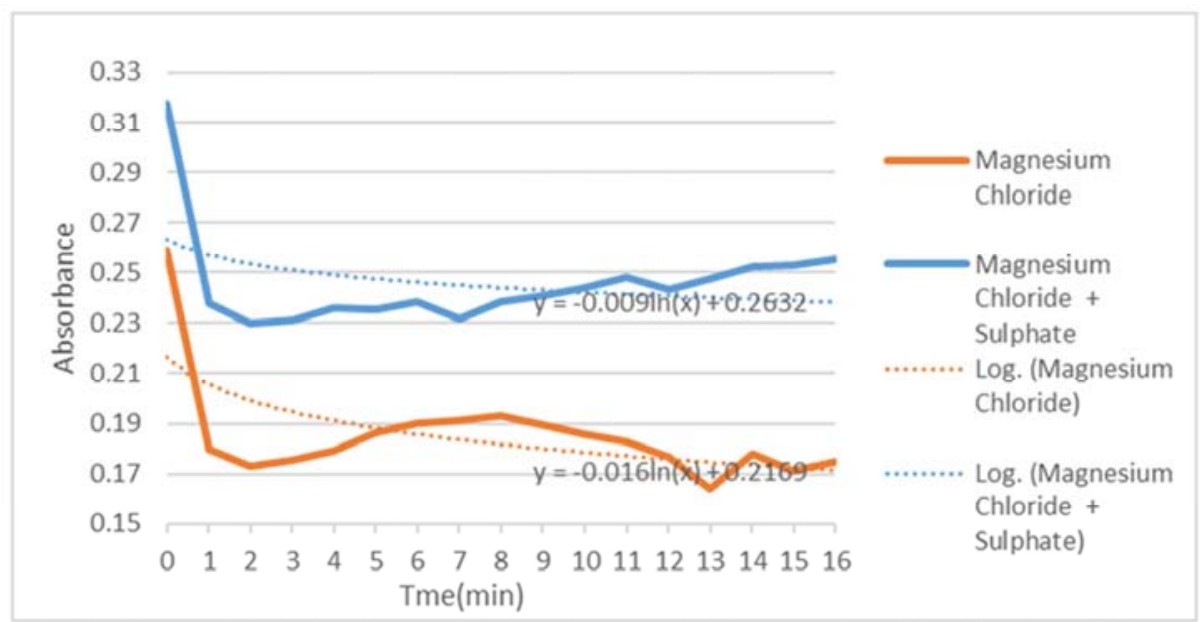

Figure 4. Effect of $\mathrm{MgSO}_{4} \cdot 7 \mathrm{H}_{2} \mathrm{O}$ on $\mathrm{MgCl}_{2} .6 \mathrm{H}_{2} \mathrm{O}$ ions permeability through $\mathrm{RBC}$ membrane. 
Table 1. Changes in absorbance of the RBC+Electrolyte solutions after 16 minutes of haemolysis*.

\begin{tabular}{|c|c|c|c|c|c|c|}
\hline & $y=m x+c$ & $y_{1}(x=1)$ & $y_{2}(x=17)$ & $\Delta y\left(y_{1}-y_{2}\right)$ & $\% \Delta y_{1,2}$ & $\% \Delta y_{a, b}$ \\
\hline $\mathrm{NaCl}$ & $y_{a}=-0.04 \ln (x)+0.189$ & 0.189 & 0.076 & 0.113 & -59.79 & \multirow{2}{*}{-60.18} \\
\hline $\mathrm{NaCl}+\mathrm{Na}_{2} \mathrm{SO}_{4}$ & $y_{b}=-0.016 \ln (x)+0.304$ & 0.304 & 0.259 & 0.045 & -14.80 & \\
\hline $\mathrm{KCl}$ & $y_{a}=-0.008 \ln (x)+0.191$ & 0.191 & 0.168 & 0.023 & -12.04 & \multirow{2}{*}{169.57} \\
\hline $\mathrm{KCl}+\mathrm{K}_{2} \mathrm{SO}_{4}$ & $y_{b}=-0.022 \ln (x)+0.331$ & 0.331 & 0.268 & 0.062 & -19.03 & \\
\hline $\mathrm{CaCl}_{2}$ & $y_{a}=0.0039 \ln (x)+0.268$ & 0.268 & 0.279 & -0.011 & 4.10 & \multirow{2}{*}{536.36} \\
\hline $\mathrm{CaCl}_{2}+\mathrm{CaSO}_{4}$ & $y_{b}=-0.017 \ln (x)+0.231$ & 0.231 & 0.183 & 0.048 & -20.78 & \\
\hline $\mathrm{MgCl}_{2}$ & $y_{a}=-0.016 \ln (x)+0.217$ & 0.217 & 0.172 & 0.045 & -20.74 & \multirow{2}{*}{-44.44} \\
\hline $\mathrm{MgCl}_{2}+\mathrm{MgSO}_{4}$ & $Y_{b}=-0.009 \ln (x)+0.263$ & 0.263 & 0.238 & 0.025 & -9.51 & \\
\hline
\end{tabular}

*Deduced from the logarithmic trendline of the graphic interpretation of the experiment's data

From the changes in absorbance of the RBC+Electrolyte solutions after 16 minutes of haemolysis deduced from the logarithmic trendline of the graphic interpretation of the experiment's data as shown in Figure 1 to 4 and Table 1, it is observed that there was a high $59.79 \%$ change in absorption of $\mathrm{RBC}$ in $\mathrm{NaCl}$ solution and a very low $4.10 \%$ increase in absorption of $\mathrm{RBC}$ in $\mathrm{CaCl}_{2}$ solution. This low increase in absorption was reversed with the addition of $\mathrm{CaSO}_{4}$. by $536.36 \%$ though $\mathrm{CaSO}_{4}$ was observed to be insoluble in water. The addition of $\mathrm{Na}_{2} \mathrm{SO}_{4}$ to $\mathrm{NaCl}$ and $\mathrm{MgSO}_{4}$ to $\mathrm{MgCl}_{2}$ resulted in a decrease in permeation rate of the resultant solutions while the addition of $\mathrm{K}_{2} \mathrm{SO}_{4}$ to $\mathrm{KCl}$ resulted to an increase in permeation rate. The increase in absorption as a result of the addition of $\mathrm{K}_{2} \mathrm{SO}_{4}$ to $\mathrm{KCl}$ was relatively high at $169.57 \%$. The observation from the addition of $\mathrm{Na}_{2} \mathrm{SO}_{4}$ to $\mathrm{NaCl}$ and the addition of $\mathrm{CaSO}_{4}$ to $\mathrm{CaCl}_{2}$ is different when compared with the results from the study of the effect of supporting electrolyte on permeation of ions through a polymeric membrane carried out by Okolue et al. [1], which shows that there was a rapid increase in the rate of permeation of $\mathrm{NaCl}, \mathrm{CaCl}_{2}$ and $\mathrm{AlCl}_{3}$ electrolytes supported by $\mathrm{Na}_{2} \mathrm{SO}_{4}, \mathrm{CaSO}_{4}$ and $\mathrm{Al}_{2}\left(\mathrm{SO}_{4}\right)$ electrolytes respectively which they reported was as a result of an increase in the concentration of $\mathrm{Na}^{+}, \mathrm{Ca}^{2+}$, and $\mathrm{Al}^{3+}$ ions in the resultant mixture. While there was an increase in the rate of permeation of both $\mathrm{CaCl}_{2}$ and $\mathrm{KCl}$, with the increase for $\mathrm{CaCl}_{2}$ observed to be three (3) times higher, a decrease at almost the same rate was observed for $\mathrm{NaCl}$ and $\mathrm{MgCl}_{2}$.

\section{Conclusion}

Supporting electrolyte concentration in the external solutions had a marked influence on the transport rate studied. $\mathrm{Na}_{2} \mathrm{SO}_{4}$ added to $\mathrm{NaCl}$ and $\mathrm{MgSO}_{4}$ to $\mathrm{MgCl}_{2}$ resulted to a decrease in permeation rate of the resultant solutions while the addition of $\mathrm{K}_{2} \mathrm{SO}_{4}$ to $\mathrm{KCl}$ and the addition of $\mathrm{CaSO}_{4}$ to $\mathrm{CaCl}_{2}$ resulted to an increase in permeation rate. In this research there is no similarity in pattern of permeation hence the effect of $\mathrm{K}_{2} \mathrm{SO}_{4}$ to $\mathrm{KCl}$ ion permeation and the effect of $\mathrm{CaSO}_{4}$ on $\mathrm{CaCl}_{2}$ ion permeation across $\mathrm{RBC}$ membrane may not be attributed to an increase in the concentration of the respective $\mathrm{K}^{+}$and $\mathrm{Ca}^{2+}$ ions in the resultant solutions.

\section{References}

[1] Okolue, B. N., Ekeocha, C. I. \& Ikeaka, B. I. (2014). Study of the effect of $\mathrm{pH}$ and supporting electrolytes on the permeation of ions, through a polymeric membrane. Chemical. Society of Nigeria, 39 (2): 40-43.

[2] IUPAC (1997). IUPAC Compendium of Chemical Terminology $2^{\text {nd }}$ edition.

[3] Wang, J. (2006). Analytical Electrochemistry, $3^{\text {rd }}$ edition, Wiley VCH. p. 118.

[4] Yoshida, H., Kawane, K., Koike, M., Mori, Y., Uchiyama, Y. \& Nagata, S. (2005). Phosphatidylserine-dependent engulfment by macrophages of nuclei from erythroid precursor cells. Nature, 437 (7059): 754-758

[5] Kundu, M. (2008). Ulk1 plays a critical role in the autophagic clearance of mitochondria and ribosomes during reticulocyte maturation. Blood, 112 (4): 1493-1502.

[6] Mortensen, M., Ferguson, D. J. \& Simon, A. K. (2010). Mitochondrial clearance by autophagy in developing erythrocytes: clearly important, but just how much so? Cell Cycle, 9 (10): 1901-1906.

[7] Yawata, Y. (2003). Cell Membrane: The RBC as a Model, Wiley-VCH

[8] Sowemimo-Coker, S. (2002). RBC haemolysis. Transfusion Medicine Review, 16: 146-60

[9] Nepal, O. \& Rao, J. P. (2011). Haemolytic effects of hypoosmotic salt solutions on human erythrocytes. Kathmandu University Medical Journey, 34 (2): 35-39.

[10] Bakko, E. L. (1985). Cell membrane physiology. In Physiology laboratory manual (unpublished). St. Olaf College, Northfield, Minnesota.

[11] Sherwood, L., Klandorf, H. \& Yancey, P. B. (2013). Animal Physiology from Genes to Organisms, $2^{\text {nd }}$ edition. Thomson Brooks/Cole, California.

[12] Benga, G. (1989). Water exchange through the erythrocytes membrane, International Review of Cytology, 114: 273-318.

[13] Ramirez, P., Alcaraz, A., Mafe, S. \& Pellicer, J. (1999). pH and supporting electrolyte concentration effects on the passive transport of cationic and anionic drugs through fixed charge membranes. Journal of Membrane Biology, 161: 143-155. 
[14] Strand, F. L. (1983). The plasma membrane as a regulatory organelle. In Physiology: A regulatory systems approach ( $2^{\text {nd }}$ edition). MacMillan, New York. Pp 49-67.
[15] Giese, A. C. (1963). Movement of solutes through the cell membrane in response to a concentration gradient. In W. B. Saunders (Ed.) Cell physiology ( $2^{\text {nd }}$ edition). Philadelphia. 